\title{
Effect of Short-Term Cigarette Smoke Exposure on Body Weight, Appetite and Brain Neuropeptide $Y$ in Mice
}

\author{
Hui Chen', Ross Vlahos ${ }^{2,3}$, Steve Bozinovski ${ }^{1,3}$, Jessica Jones ${ }^{1,3}$, Gary P Anderson ${ }^{1,2,3}$ and Margaret J Morris*, \\ 'Department of Pharmacology, The University of Melbourne, Victoria, Australia; ${ }^{2}$ Department of Medicine, The University of Melbourne, Royal \\ Melbourne Hospital, Victoria, Australia; ${ }^{3}$ CRC for Chronic Inflammatory Diseases, The University of Melbourne, Victoria, Australia
}

\begin{abstract}
Although nicotinic receptors have been demonstrated in hypothalamic appetite-regulating areas and nicotine administration alters food intake and body weight in both animals and humans, the mechanisms underlying the effects of smoking on appetite circuits remain unclear. Conflicting effects of nicotine on the major orexigenic peptide, neuropeptide Y (NPY), have been observed in the brain, but the effects of smoking are unknown. Thus, we aimed to investigate how cigarette smoking affects body weight, food intake, plasma leptin concentration, hypothalamic NPY peptide, adipose mass and mRNA expression of uncoupling proteins (UCP), and tumor necrosis factor (TNF) $\alpha$. Balb/C mice ( 8 weeks) were exposed to cigarette smoke (three cigarettes, three times a day for 4 consecutive days) or sham exposed. Body weight and food intake were recorded. Plasma leptin and brain NPY were measured by radioimmunoassay. UCPs and TNF $\alpha$ mRNA were measured by real-time PCR. Food intake dropped significantly from the first day of smoking, and weight loss became evident within 2 days. Brown fat and retroperitoneal white fat masses were significantly reduced, and plasma leptin concentration was decreased by $34 \%$, in line with the decreased fat mass. NPY concentrations in hypothalamic subregions were similar between two groups. UCPI mRNA was decreased in white fat and UCP3 mRNA increased in brown fat in smoking group. Short-term cigarette smoke exposure led to reduced body weight, food intake, and fat mass. The reduction in plasma leptin concentration may have been too modest to increase NPY production; alternatively, change in NPY or its function might have been offset by nicotine or other elements in cigarette smoke.

Neuropsychopharmacology (2005) 30, 7|3-719, advance online publication, 27 October 2004; doi: I 0.1038/sj.npp. I 300597
\end{abstract}

Keywords: anorexia; weight loss; cigarette smoking; adipose tissue; uncoupling protein; tumor necrosis factor $\alpha$

\section{INTRODUCTION}

An inverse relationship between cigarette smoking and body weight has been documented in many studies. Smokers weigh less than nonsmokers of the same age and gender, and anorexia often occurs with cigarette smoking (Albanes et al, 1987; Klesges et al, 1989; Perkins, 1992). Cessation of smoking without nicotine replacement therapy is usually accompanied by weight gain (Stamford et al, 1986; Levin et al, 1987; Williamson et al, 1991; O'Hara et al, 1998). As a consequence, some people are willing to use smoking in order to lose or maintain their body weight, and are reluctant to stop smoking due to concerns about weight

Part of this work was presented in abstract form to the 24th annual meeting of Australian Neuroscience Society, January 2004.

*Correspondence: Assoc Professor Dr MJ Morris, Department of Pharmacology, The University of Melbourne, Victoria 3010, Australia, Tel: 6 I 38344 5745, Fax: 6138344 024I,

E-mail: mjmorris@unimelb.edu.au

Received 28 June 2004; revised 9 September 2004; accepted 21 September 2004

Online publication: 24 September 2004 at http://www.acnp.org/citations/ Npp092404040294/default.pdf gain on cessation, especially among younger smokers (Crisp et al, 1999; Wee et al, 2001). The effects of cigarette smoking on appetite may also contribute to the morbidity and mortality of smokers with chronic lung disease and wasting.

This action of smoking on body weight appears to be nicotine mediated as indicated by Hajek et al (1988). Previous studies in both humans and animals have reported that nicotine administration decreases body weight and caloric intake (Wager-srdar et al, 1984; Grunberg et al, 1986; Hajek et al, 1988; Bellinger et al, 2003; Bishop et al, 2004). Thus, the effects of nicotine to suppress appetite and decrease food intake leading to reduced body weight are not confined to human subjects.

The brain responds to altered energy homeostasis by adjusting food intake. Neuropeptides in the hypothalamus play a pivotal role in regulating food intake, and their actions in this region are known to be modulated by circulating factors such as leptin. Neuropeptide Y (NPY), a 36-amino-acid neuropeptide, which is abundant in the mammalian brain and highly concentrated in the hypothalamus, is known to play a central role in hypothalamic mechanisms, which increase food intake (Woods et al, 1998). Nicotine binding sites have been demonstrated in 
appetite-regulating regions of the hypothalamus, suggesting that centrally mediated actions of nicotine may contribute to the reduced appetite and body weight loss (Jo et al, 2002). If NPY signaling is a possible target for nicotine's anorexic effects, a suppression of NPY expression might be expected with nicotine treatment. Frankish and co-workers found that both acute $(24 \mathrm{~h})$ and longer-term (2 week) nicotine injection decreased NPY content and NPY mRNA expression in the arcuate nucleus (Arc) and paraventricular nucleus (PVN) of the rat; however, $\mathrm{Li}$ and co-workers have shown a positive correlation between NPY mRNA expression and the dose of nicotine used (Frankish et al, 1995; Li $e t$ al, 2000). Thus, the picture with regard to the effects of nicotine on NPY in the central nervous system is unclear. Further, the effects of smoking, rather than nicotine, on brain mediators involved in appetite regulation, have not been investigated to date.

In addition to examining NPY, we also investigated the effects of smoking on other markers of obesity and energy homeostasis, such as leptin and uncoupling proteins (UCP). Leptin is a hormone secreted by adipose tissue that is known to act centrally to inhibit the effects of NPY, apparently by inhibiting its synthesis in the Arc (Stephens et al, 1995; Cusin et al, 1996; Erickson et al, 1996; Elmquist et al, 1999). The distribution of leptin receptors was found to overlap with that of nicotinic receptors in the hypothalamus, indicating a possible link between these two factors (Jo et al, 2002). UCPs are mitochondrial carrier proteins, which are able to dissipate the proton gradient of the inner mitochondrial membrane. This uncoupling process reduces the amount of ATP generated through oxidation of fuels and increases thermogenesis, which is related to energy metabolism (Dalgaard and Pedersen, 2001).

Smoking exerts an inflammatory stimulus on macrophages, which brings about the production of inflammatory cytokines, such as tumor necrosis factor (TNF) $\alpha$, which might be an important early event in the development of disease states associated with smoking (Fernandez-Real et al, 2003). Increased TNF $\alpha$ activity (Fernandez-Real et al, 2003) and decreased actions have been observed in smokers and nicotine administration studies (Ouyang et al, 2000; Liu et al, 2001). Produced by both immunocompetent cells and adipocytes, TNF $\alpha$ can regulate lipid metabolism, adipocyte differentiation, inhibit appetite, and is a mediator of cachexia (Torti et al, 1989; Spiegelman and Hotamisligil, 1993; Ventre et al, 1997; Bullo-Bonet et al, 1999; Langhans and Hrupka, 1999). Therefore, we also determined the effect of cigarette smoke exposure on TNF $\alpha$ expression in adipose tissue.

Therefore, the aim of this study was to measure the changes in food intake, body weight, hypothalamic NPY content, and expression of UCP1, UCP3, and TNF $\alpha$ mRNA in fat tissue in response to short-term (4 days) cigarette smoke exposure in mice.

\section{MATERIALS AND METHODS}

\section{Animals}

Development of respiratory disease following cigarette smoke exposure is strain dependent (Guerassimov et al, 2004), and in this study, Balb/C mice were selected based on the inflammatory and cytokine responses in related respiratory studies in our laboratory. Male Balb/C mice (aged 7 weeks, $n=32$ ) were obtained from the Animal Resource Centre Pty Ltd (Perth, Australia), and were housed at $20 \pm 2^{\circ} \mathrm{C}$ in microisolator cages, and maintained on a 12:12 h light/dark cycle (lights on at 0600). They were allowed ad libitum access to standard rodent chow and water. Mice were allowed a week to adapt to their new environment. Animals were monitored daily; food intake per cage and individual body weight were measured three times per week during this period. After acclimatization, mice were randomly divided into two groups, cigarette smoke exposed (smoking group) or sham exposed (control group). The animals exposed to cigarette smoke were placed inside a perspex chamber (181) and exposed to the smoke produced by three cigarettes (Winfield Red, $16 \mathrm{mg}$ or less of tar, $1.2 \mathrm{mg}$ or less of nicotine, and $15 \mathrm{mg}$ or less of $\mathrm{CO}$ ), three times $(0900,1200$ and 1500) a day for 4 consecutive days. Control mice were handled similarly without smoke exposure. Food intake and body weight were measured daily. All procedures were approved by the Animal Experimentation Ethics Committee of The University of Melbourne.

\section{Sample Collection}

On the 5th day, mice were anesthetized (ketamine/xylazine $15 / 30 \mathrm{mg} / \mathrm{kg}$, intraperitoneal), and blood was collected from the abdominal vena cava into heparinized tubes (5000 IU/ ml; Fisons, Australia), and centrifuged at 10000 r.p.m. and $4^{\circ} \mathrm{C}$ for $8 \mathrm{~min}$. Separated plasma was stored at $-80^{\circ} \mathrm{C}$ for subsequent determination of plasma leptin and corticosterone concentrations. Mice were decapitated and the brain removed and rapidly dissected on ice into regions containing $\mathrm{PVN}, \mathrm{Arc}$, anterior and posterior hypothalamus (AH and $\mathrm{PH}$ ), and medulla. Brain regions were weighed and stored at $-80^{\circ} \mathrm{C}$ for later determination of NPY peptide content. Body fat (brown adipose tissue (BAT), left retroperitoneal white adipose tissue (RpWAT), testicular WAT) and liver were dissected and weighed. BAT and RpWAT were stored at $-80^{\circ} \mathrm{C}$ for later measurement of mRNA of $\mathrm{UCP} 1, \mathrm{UCP} 3$, and TNF $\alpha$.

\section{Brain NPY, Plasma Leptin, and Corticosterone Assays}

Endogenous NPY from the various brain regions was extracted by boiling the tissues in $0.5 \mathrm{M}$ acetic acid, homogenization by hand with a glass homogenizer, and centrifugation at 7500 r.p.m. for $30 \mathrm{~min}$ at $4^{\circ} \mathrm{C}$. The supernatant was decanted, and $50 \mu \mathrm{l}$ samples were lyophilized and reconstituted with assay buffer $(0.04 \mathrm{M}$ sodium phosphate buffer containing $0.01 \mathrm{M}$ EDTA, $0.1 \mathrm{M} \mathrm{NaCl}$, $0.02 \% \mathrm{NaN}_{3}, 0.25 \%$ BSA ( $\mathrm{pH}$ 7.3)). NPY-like immunoreactivity in the various brain regions was measured by a specific radioimmunoassay developed in our laboratory using synthetic NPY as standard (10-1280 pg/tube, Auspep, Australia) (Morris et al, 1986). Samples were incubated with NPY antibody overnight at $\left.4{ }^{\circ} \mathrm{C} .{ }^{[125} \mathrm{I}\right] \mathrm{NPY}$ labeled with Bolton and Hunter reagent $(3000 \mathrm{Ci} / \mathrm{mmol}$, Amersham, Australia) was added and the incubation continued overnight. Bound and free radioligand were separated by the addition of nonimmunized rabbit serum and sheep anti- 
rabbit second antibody followed by centrifugation at 3000 r.p.m. at $4^{\circ} \mathrm{C}$ for $35 \mathrm{~min}$ (RT7, Sorvall instruments). The bound fraction was then counted in a gamma counter. The detection limit for the radioimmunoassay was routinely $2 \mathrm{pg} \mathrm{NPY} /$ tube and the intra- and interassay coefficients of variation were 6 and 13\%, respectively. NPY in each brain region was calculated as ng NPY/mg tissue. Plasma leptin and corticosterone concentrations were measured using a commercially available radioimmunoassay kit (Linco, MI, USA, and MP Biomedicals Europe, Belgium, respectively).

\section{UCP1, UCP3, and TNF $\alpha$ Measurement}

Total RNA was isolated from $10 \mathrm{mg}$ of both WAT and BAT using an RNAeasy kit (Qiagen) according to the manufacturer's instructions. The purified total RNA rep was used as a template to generate first-strand cDNA synthesis using Super Script II (Invitrogen) as described previously (Bozinovski et al, 2004). The reaction mix containing $1 \mu \mathrm{g}$ of RNA, $250 \mathrm{ng}$ of random hexamers (Promega), and $10 \mathrm{mM}$ dNTP mix was diluted to $12 \mu \mathrm{l}$ in sterile water, heated to $65^{\circ} \mathrm{C}$ for $5 \mathrm{~min}$ and chilled on ice for $1 \mathrm{~min}$. First-strand synthesis was then performed in a $20 \mu \mathrm{l}$ total reaction volume by adding $50 \mathrm{mM}$ Tris- $\mathrm{HCl}(\mathrm{pH} 8.3), 75 \mathrm{mM} \mathrm{KCl}$, $3 \mathrm{mM} \mathrm{MgCl}, 10 \mathrm{mM}$ DTT, $40 \mathrm{U}$ RNaseout and $200 \mathrm{U}$ Superscript II reverse transcriptase enzyme at $42^{\circ} \mathrm{C}$ for $50 \mathrm{~min}$. The reaction was inactivated by heating at $70^{\circ} \mathrm{C}$ for 15 min. cDNA was diluted 10 -fold in sterile water and stored at $-20^{\circ} \mathrm{C}$ prior to amplification. Quantitative real-time PCR was performed as described previously (ABI PRISM 7900 HT Sequence Detection System) (Bozinovski et al, 2004) using predeveloped primers from Applied Biosystem. Briefly, gene expression was quantified by multiplexing single reaction, where our gene of interest (UCP1, UCP3, and TNF $\alpha$ ) was standardized to control (18s rRNA). An individual BAT sample from the control group was then arbitrarily assigned as a calibrator against which all other samples are expressed as a fold difference.

\section{Statistical Analyses}

Results are expressed as mean \pm SEM. Body weight of smoke-exposed and control mice were analyzed using analysis of variance with repeated measures, followed by a post hoc least significance difference test. Difference in daily food intake, fat and organ mass, plasma leptin and corticosterone concentrations, brain NPY concentration and content, and relative expression of mRNA were analyzed using Student's unpaired $t$-tests. The relation between plasma leptin concentration and body weight, body weight gain and WAT was examined using simple linear regression.

\section{RESULTS}

Both food intake and body weight of the two experimental mice groups were well matched at the beginning of this study as shown by Figure 1a and b, respectively. Over the whole experimental period, daily food intake of control mice was stable. After the first day of cigarette smoke exposure, food intake was somewhat lower than control mice, and this difference increased over time. From the
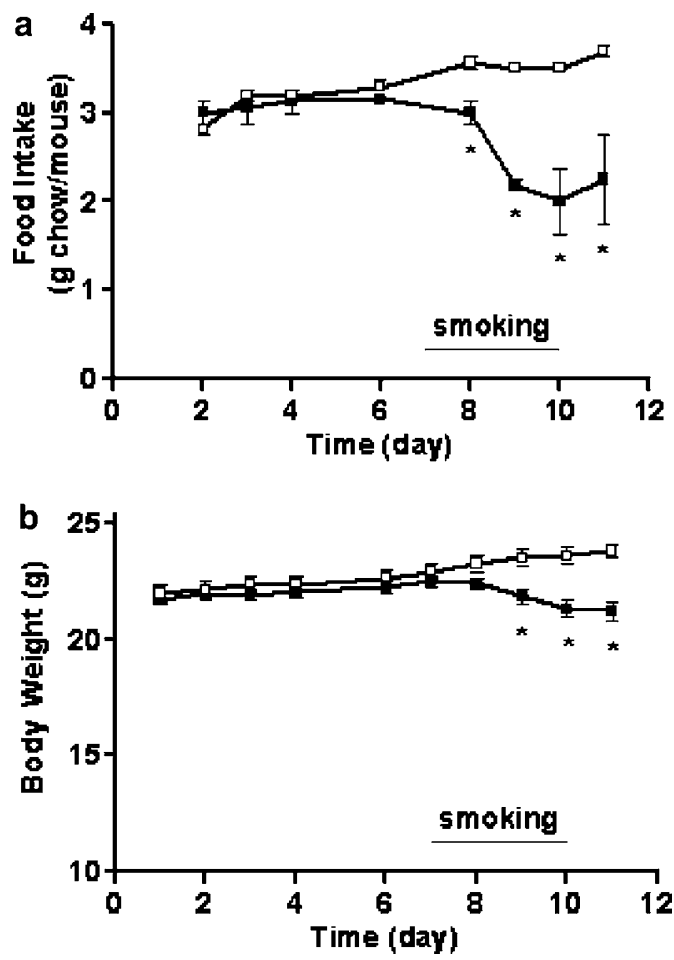

Figure I (a) Food intake (g chow/mouse/day) of control (open bar) and smoking (filled bar) Balb/C mice during experimental period. Mice were exposed to cigarette smoke or sham exposed from day 7 to 10 . Results are expressed as mean \pm SEM of 16 mice in each group. *Significant difference between treatment groups $(p<0.05)$. (b) Body weight of control mice (open bar, $n=16$ ) and smoking mice (filled bar, $n=16$ ) during the experimental period. Mice were exposed to cigarette smoke or sham exposed from day 7 to 10 . Results are expressed as mean \pm SEM. *Significant difference between treatment groups $(p<0.05)$

second day of smoke exposure, food intake was reduced to $60 \%$ of the control level (Figure 1a, $p<0.05$ ). The total 4 day chow intake of the mice exposed to cigarette smoke was reduced by $34 \%$ (9.4 vs $14.3 \mathrm{~g} /$ mouse in control mice, $p<0.05)$. There was a time effect on the growth of control mice, reflecting weight gain, which was opposite in the smoking group $(p<0.05$, Figure $1 \mathrm{~b})$. Body weight of the smoking group was significantly reduced within 2 days of cigarette smoking $(21.9 \pm 0.3 v s 23.6 \pm 0.3 \mathrm{~g}$ for smoking and control group, respectively, $p<0.05$, Figure $1 \mathrm{~b}$ ) and pretreatment (day 7) levels $(p<0.05$, Figure 1b). After 4 days of cigarette smoke exposure, the average body weight of the smoking group was $10 \%$ less than the control group $(p<0.05$, Table 1$)$.

Animals exposed to 4 days of cigarette smoke displayed lower weights of the liver, BAT, and RpWAT relative to control mice $(p<0.05$, Table 1$)$. Notably for BAT and RpWAT, these differences were still pronounced when data were calculated as a percentage of body weight (BAT $0.38 \pm 0.02$ vs $0.47 \pm 0.02 \%$; RpWAT $0.48 \pm 0.04 \quad v s$ $0.59 \pm 0.03 \%$, in smoking and control group, respectively, $p<0.05)$. Plasma leptin concentrations in the smoking group decreased significantly, in line with the decreased white fat mass $(p<0.05$, Table 1$)$. When both groups were combined, plasma leptin concentration was significantly correlated with WAT, body weight, and body weight gain $(r=0.60,0.54$, and 0.58 , respectively, $p<0.05, n=15)$. No 
Table I Effect of Cigarette Smoke Exposure on Body Weight, Liver, Adipose Tissue Mass, Plasma Leptin, and Corticosterone Concentration

\begin{tabular}{lcc}
\hline & Control & Smoke exposure \\
\hline Body weight (pre-exposure) (g) & $23.0 \pm 0.3$ & $22.5 \pm 0.2$ \\
Body weight (postexposure) (g) & $23.6 \pm 0.3$ & $21.3 \pm 0.4^{*}$ \\
Liver (mg) & $1188.5 \pm 38.5$ & $929.8 \pm 20.3^{*}$ \\
BAT (mg) & $110.7 \pm 6.5$ & $80.0 \pm 4.0^{*}$ \\
RpWAT (mg) & $139.1 \pm 7.7$ & $104.3 \pm 9.7 *$ \\
Testicular WAT (mg) & $471.7 \pm 24.9$ & $416.4 \pm 34.9 *$ \\
Leptin (ng/ml) & $6.5 \pm 0.5$ & $4.3 \pm 0.5 *$ \\
Corticosterone (ng/ml) & $212.4 \pm 50.7$ & $247.3 \pm 33.6$ \\
\hline
\end{tabular}

Results are expressed as mean \pm SEM (for body weights, $n=32$; for tissue masses, $n=11$, 12, respectively; for plasma hormone concentrations, $n=8,7$, respectively).

*Significantly different from control mice $(P<0.05)$.

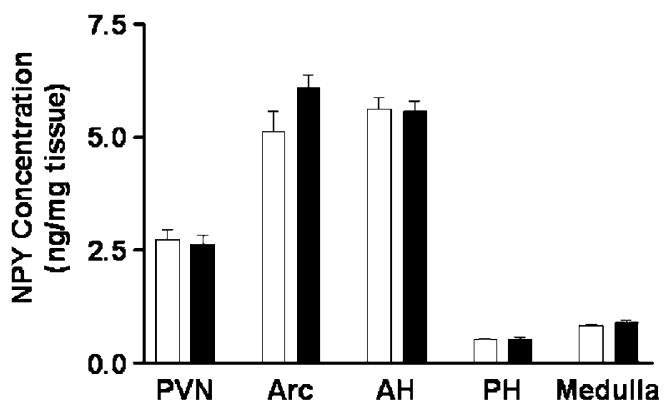

Figure 2 NPY concentration of brain regions of control mice (open bar. $n=8$ ) and smoking mice (filled bar, $n=7$ ) after 4 days cigarette smoke exposure. Results are expressed as mean \pm SEM.

difference in plasma corticosterone levels was observed between treatment groups at the end of the experiment (Table 1).

NPY concentrations of the hypothalamic regions, $\mathrm{AH}, \mathrm{PH}$, PVN, and Arc, as well as medulla, were not different between the control and the smoking groups at the end of the experiment (Figure 2). The total hypothalamic NPY content was not altered by 4 days smoke exposure (smoking group $82.3 \pm 1.9 \mathrm{ng} v s$ control group $86.2 \pm 2.9 \mathrm{ng}$ ).

UCP1 mRNA expression was decreased by $76 \%$ in WAT in the smoking group, but no difference was found in BAT between the smoking and control group. BAT UCP3 mRNA expression was significantly increased in cigarette smokeexposed mice, while no change was observed in WAT. TNF $\alpha$ mRNA expression was not affected by cigarette smoking in either WAT or BAT (Figure 3).

\section{DISCUSSION}

In this study, we examined the hormonal, neurochemical, and metabolic changes induced by short-term (4 consecutive days) cigarette smoke exposure in mice. Using this protocol, we previously determined blood carboxyhemoglobin content to be $3 \%$ (unpublished observation),

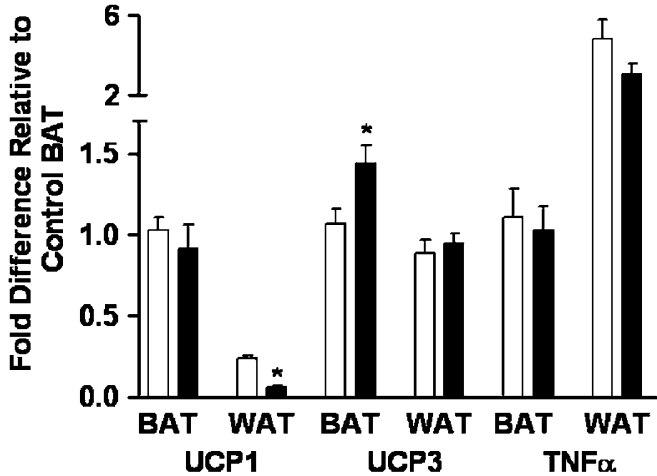

Figure $3 \mathrm{UCPI}, \mathrm{UCP} 3$, and TNF $\alpha$ mRNA expression in BAT and WAT of control mice (open bar, $n=7$ ) and smoking mice (filled bar, $n=8$ ) after 4 days cigarette smoke exposure, standardized to $18 \mathrm{~s}$ rRNA, expressed relative to a BAT sample from the control group (fold difference). Results are expressed as mean \pm SEM. *Significantly different from control group $(p<0.05)$.

suggesting a moderate level of smoke exposure in the smoking group, compared to $10-14 \%$ in heavy smokers (Benowitz et al, 1982). When exposed to cigarette smoke, the mice showed a consistent reduction in chow intake compared to both their baseline levels before cigarette smoke exposure was implemented, and the chow intake of the control group. The unchanged levels of plasma corticosterone, a stress response hormone, between experimental groups, suggest that decreased food intake might not be due to any greater stress related to smoke exposure. This reduced appetite with smoke exposure is consistent with the anorexia commonly observed among human smokers and previous studies using nicotine administration (Grunberg et al, 1986; Albanes et al, 1987; Levin et al, 1987; Hajek et al, 1988; Klesges et al, 1989; Bellinger et al, 2003; Bishop et al, 2004). However, clearly, it is difficult to draw comparisons between the experiments using nicotine administration and effects of cigarette smoke, which contains multiple factors, and can cause inflammatory changes, which might alter energy metabolism. The decreased food intake most likely led to the significant reduction in body weight, which was $10 \%$ less than control mice at death, reflected by a significant reduction in adipose tissue, particularly white fat masses. When data were calculated as a percentage of body weight, white fat masses remained significantly reduced in the smoking group, indicating that decreased body fat largely contributed to the reduced body weight, and suggesting that fat deposits might be used as an energy supply under these conditions of negative energy balance. The anorexia and weight loss caused by cigarette smoke exposure in mice appears to resemble the effects of cigarette smoking in humans.

NPY is synthesized in the Arc, from where cells project to the PVN and other hypothalamic areas (Bai et al, 1985; Chronwall et al, 1985). Exogenous administration of NPY into the cerebroventricle results in a dramatically increased carbohydrate and fat intake and decreased energy expenditure in rodents, and eventually, to a state of obesity (Zarjevski et al, 1993). NPY peptide production is increased with starvation, food restriction and in genetically obese 
animals (eg ob/ob mice), and decreased with refeeding, suggesting that NPY may be a critical mediator for the maintenance of body weight (Beck et al, 1990; Brady et al, 1990; Wilding et al, 1993; Swart et al, 2002). Since nicotinic receptors have been demonstrated in the appetite-regulating area of the hypothalamus, cigarette smoking might change appetite in mice by affecting the energy homeostasis circuits including both those releasing orexigenic peptides, such as NPY and melanin concentrating hormone, and anorexigenic peptides, such as cocaine- and amphetamine-regulated transcript and pro-opiomelanocortin (Jo et al, 2002). However, NPY concentrations in the hypothalamic subregions, $\mathrm{AH}, \mathrm{PVN}, \mathrm{PH}$, and Arc, as well as the medulla, were not affected by 4 days of smoke exposure. In previous nicotine administration studies in rat, decreased NPY peptide in PVN and Arc was observed after $24 \mathrm{~h}$ of highdose $(12 \mathrm{mg} / \mathrm{kg} /$ day $)$ nicotine administration that reduced food intake by $30 \%$ (Frankish et al, 1995), while food intake of mice exposed to cigarette smoke in the present study was only $16 \%$ less than control mice in the first $24 \mathrm{~h}$, suggesting the extent of negative energy status induced by the cigarette smoke exposure we used might be insufficient to regulate hypothalamic NPY. However, in another study, hypothalamic NPY peptide was found to be increased after 14 days of low-dose ( $4 \mathrm{mg} / \mathrm{kg} /$ day) nicotine treatment, which reduced food intake by $19.5 \%$ in rats (Li et al, 2000), suggesting that the present treatment may have been too short to cause significant changes in NPY peptide. Furthermore, previously it was found that nicotine can directly inhibit the hyperphagia produced by exogenous administration of NPY into the PVN (Bishop et al, 2002), suggesting it is possible that the effects of brain NPY can be offset by nicotine or other elements in cigarette smoke. The effects of nicotine administration on NPY peptide in mice have not been documented previously. Decreased leptin levels would normally decrease the inhibitory effects of leptin on NPY and thus increase NPY production (Stephens et al, 1995; Elmquist et al, 1999). Although we have previously described significant negative correlations between plasma leptin and hypothalamic NPY in a number of paradigms including weight loss following vagotomy (Furness et al, 2001), and chronic high fat diet (Hansen et al, 2004), the impact of cigarette smoke exposure on leptin here was relatively modest compared to these interventions.

In addition to the decreased food intake, it is possible that other factors involved in energy balance may also have contributed to the decreased body weight observed in mice exposed to cigarette smoke. While it is generally accepted that UCP1 is exclusively expressed in BAT in rodents, it can be induced in WAT at a lower levels than in BAT (Nagase et al, 1996; Yoshida et al, 1999). In our study, UCP1 in BAT was not affected by 4 days smoke exposure, suggesting BAT thermogenesis was largely unaffected by cigarette smoking in this protocol. By using quantitative real-time PCR, UCP1 mRNA can be detected under basal conditions in WAT in mice. The expression of UCP1 mRNA in WAT was found to be significantly decreased by cigarette smoke exposure. However previously, it was reported that UCP1 mRNA can be induced in both BAT and WAT by nicotine treatment, probably enhancing the energy expenditure in this situation (Yoshida et al, 1999; Arai et al, 2001). These changes highlight the need to examine metabolic effects of smoking per se rather than nicotine administration. Fasting and chronic food deprivation can downregulate UCP1 expression in BAT (Samec et al, 1998; Sivitz et al, 1999), with changes in WAT unknown. However, in our study, a $34 \%$ reduction of total food intake over 4 days cigarette smoke exposure did not affect UCP1 mRNA expression in BAT, but reduced it in WAT. Although overexpression of UCP1 mRNA in WAT can cause obesity resistance (Kopecky et al, 1996), it is not clear as to how the decreased UCP1 mRNA might contribute to the maintenance of energy balance in this situation. It is difficult to separate any effects of nicotine or food restriction on UCP1, as both have been shown to regulate expression of UCPs.

UCP3, a homolog of UCP1, is expressed in BAT and skeletal muscle and is implicated in the regulation of mitochondrial fatty acid transport and influences basal metabolic rate (Samec et al, 1998). In our study, UCP3 mRNA was significantly increased in BAT in the face of the reduced food intake following smoke exposure, which was opposite to previous studies where the UCP3 mRNA expression in BAT was downregulated by fasting and food deprivation, a physiological response to conserve energy expenditure (Samec et al, 1998; Sivitz et al, 1999). The role of UCP3 in lipid regulation in skeletal muscle can be extended to BAT (Samec et al, 1998). An increase in UCP3 would increase uncoupling of mitochondrial respiration and increase energy expenditure or heat dissipation, which suggests that in the smoke-exposed mice, lipid utilization and energy expenditure were upregulated, rather than decreasing energy expenditure to maintain homeostasis. Thus, cigarette smoke exposure probably disturbs energy homeostasis, which may crucially contribute to the weight and adipose loss observed. Very little data exist on the effects of nicotine administration on BAT UCP3 mRNA expression in rodents to date.

TNF $\alpha$ is increasingly recognized to be involved in the pathogenesis of obesity, and its activation seems to be associated with increased energy expenditure and weight loss (Toomey et al, 1995; Tracey and Cerami, 1992). Previously, it was found that TNF $\alpha$ is increased in patients with anorexia (Vaisman and Hahn, 1991), and exogenous administration of TNF $\alpha$ had inhibitory effects on food intake in rats (Fantino and Wieteska, 1993; Sonti et al, 1996; McCarthy, 2000). In addition, TNF $\alpha$ can affect lipid metabolism in vivo by increasing lipolysis in adipose tissue, and inhibit adipose cell differentiation in vitro (Torti et al, 1989; De clercq et al, 1996; Kern, 1997). However, our observation of no change in TNF $\alpha$ mRNA expression in both BAT and WAT suggests that TNF $\alpha$ (at least in adipose tissue) did not contribute to anorexia and the loss of fat deposits following cigarette smoke exposure.

In summary, 4 days cigarette smoking caused loss of appetite and body weight in mice, and accordingly negative energy balance, but increased lipid utilization and energy expenditure reflected by an induced UCP3 mRNA expression in BAT. Hypothalamic NPY concentration and content were not changed by 4 days cigarette smoke exposure, probably due to the short-term nature of this experiment or the inhibitory effects of cigarette smoke exposure. Further work is underway to determine the effects of more chronic periods of cigarette smoking. 


\section{ACKNOWLEDGEMENTS}

This work was funded by National Health and Medical Research Council of Australia and the CRC for Chronic Inflammatory Diseases. We thank Dr Michelle J Hansen for helpful discussion.

\section{REFERENCES}

Albanes D, Jones DY, Micozzi MS, Mattson ME (1987). Association between smoking and body weight in the US population: analysis of NHANES II. Am J Public Health 77: 439-444.

Arai K, Kim K, Kaneko K, Iketani M, Otagiri A, Yamauchi N et al (2001). Nicotine infusion alters leptin and uncoupling protein 1 mRNA expression in adipose tissues of rats. Am J Physiol Endocrinol Metab 280: E867-E876.

Bai FL, Yamano M, Shiotani Y, Emson PC, Smith AD, Powell JF et al (1985). An arcuato-paraventricular and-dorsomedial hypothalamic neuropeptide Y-containing system which lacks noradrenaline in the rat. Brain Res 331: 172-175.

Beck B, Jhanwar-Uniyal $M$, Burlet A, Chapleur-Chateau $M$, Leibowitz SF, Burlet C (1990). Rapid and localized alternation of neuropeptide $\mathrm{Y}$ in discrete hypothalamic nuclei with feeding status. Brain Res 528: 245-249.

Bellinger L, Cepeda-Benito A, Wellman PJ (2003). Meal patterns in male rats during and after intermittent nicotine administration. Pharmacol Biochem Behav 74: 495-504.

Benowitz NL, Kuyt F, Jacob III P (1982). Circadian blood nicotine concentrations during cigarette smoking. Clin Pharmacol Ther 32: 758-764.

Bishop C, Parker GC, Coscina DV (2002). Nicotine and its withdrawal alter feeding induced by paraventricular hypothalamic injections of neuropeptide $\mathrm{Y}$ in Sprague-Dawley rats. Psychopharmacology (Berl) 162: 265-272.

Bishop C, Parker GC, Coscina DV (2004). Systemic nicotine alters whole-body fat utilization in female rats. Physiol Behav 80: 563-567.

Bozinovski S, Jones J, Beavitt SJ, Cook AD, Hamilton JA, Anderson GP (2004). Innate immune responses to LPS in mouse lung are suppressed and reversed by neutralization of GM-CSF via repression of TLR-4. Am J Physiol Lung Cell Mol Physiol 286: L877-L885.

Brady LS, Smith MA, Gold PW, Herkenham M (1990). Altered expression of hypothalamic neuropeptide mRNAs in food-restricted and food-deprived rat. Neuroendocrinology 52: 441-447.

Bullo-Bonet M, Garcia-Lorda P, Lopez-Soriano FJ, Argiles JM, Salas-Salvado J (1999). Tumor necrosis factor, a key role in obesity? FEBS Lett 451: 215-219.

Chronwall BM, DiMaggio DA, Massari VJ, Pickel VM, Ruggiero DA, O'Donohue TL (1985). The anatomy of neuropeptideY-containing neurons in rat brain. Neuroscience 15: 1159-1181.

Crisp A, Sedgwick P, Halek C, Joughin N, Humphrey H (1999). Why may teenage girls persist in smoking? J Adolesc 22: 657-672.

Cusin I, Rohner-Jeanrenaud F, Stricker-Krongrad A, Jeanrenaud B (1996). The weight-reducing effect of an intracerebroventricular bolus injection of leptin in genetically obese $f a / f a$ rats. Reduced sensitivity compared with lean animals. Diabetes 45 : 1446-1450.

Dalgaard LT, Pedersen O (2001). Uncoupling proteins: functional characteristics and role in the pathogenesis of obesity and Type II diabetes. Diabetologia 44: 946-965.

De clercq L, Genart C, Boone C, Remacle C (1996). Effects of acute or chronic administration of tumor necrosis factor on rat adipose tissue development. J Anim Sci 74: 2745-2751.

Elmquist JK, Elias CF, Saper CB (1999). From lesions to leptin: hypothalamic control of food intake and body weight. Neuron 22: $221-232$.
Erickson JC, Hollopeter G, Palmiter RD (1996). Attenuation of the obesity syndrome of ob/ob mice by the loss of neuropeptide $\mathrm{Y}$. Science 274: 1704-1707.

Fantino M, Wieteska L (1993). Evidence for a direct central anorectic effect of tumor-necrosis-factor-alpha in the rat. Physiol Behav 53: 477-483.

Fernandez-Real JM, Broch M, Vendrell J, Ricart W (2003). Smoking, fat mass and activation of the tumor necrosis factoralpha pathway. Int J Obes Relat Metab Disord 27: 1552-1556.

Frankish HM, Dryden S, Wang Q, Bing C, MacFarlane IA, Williams $G$ (1995). Nicotine administration reduces neuropeptide $Y$ and neuropeptide $\mathrm{Y}$ mRNA concentrations in the rat hypothalamus: NPY may mediate nicotine's effects on energy balance. Brain Res 694: 139-146.

Furness JB, Koopmans HS, Robbins HL, Clerc N, Tobin JM, Morris MJ (2001). Effects of vagal and splanchnic section on food intake, weight, serum leptin and hypothalamic neuropeptide $\mathrm{Y}$ in rat. Auton Neurosci 92: 28-36.

Grunberg NE, Bowen DJ, Winders SE (1986). Effects of nicotine on body weight and food consumption in female rats. Psychopharmacology (Berl) 90: 101-105.

Guerassimov A, Hoshino Y, Takubo Y, Turcotte A, Yamamoto M, Ghezzo $\mathrm{H}$ et al (2004). The development of emphysema in cigarette smoke exposed mice is strain dependent. Am J Respir Crit Care Med 170: July 28 [Epub ahead of print].

Hajek P, Jackson P, Belcher M (1988). Long-term use of nicotine chewing gum. Occurrence, determinants, and effect on weight gain. JAMA 260: 1593-1596.

Hansen MJ, Jovanovska V, Morris MJ (2004). Adaptive responses in hypothalamic neuropeptide $\mathrm{Y}$ in the face of prolonged highfat feeding in the rat. J Neurochem 88: 909-916.

Jo YH, Talmage DA, Role LW (2002). Nicotinic receptor-mediated effects on appetite and food intake. J Neurobiol 53: 618-632.

Kern PA (1997). Potential role of TNFalpha and lipoprotein lipase as candidate genes for obesity. J Nutr 127: 1917S-1922S.

Klesges RC, Meyers AW, Klesges LM, La Vasque ME (1989). Smoking, body weight, and their effects on smoking behavior: a comprehensive review of the literature. Psychol Bull 6: 204-230.

Kopecky J, Hodny Z, Rossmeisl M, Syrovy I, Kozak LP (1996). Reduction of dietary obesity in aP2-Ucp transgenic mice: physiology and adipose tissue distribution. Am J Physiol 270: E768-E775.

Langhans W, Hrupka B (1999). Interleukins and tumor necrosis factor as inhibitors of food intake. Neuropeptides 33: 415-424.

Levin ED, Morgan MM, Galvez C, Ellison GD (1987). Chronic nicotine and withdrawal effects on body weight and food and water consumption in female rats. Physiol Behav 39: 441-444.

Li MD, Kane JK, Parker SL, McAllen K, Matta SG, Sharp BM (2000). Nicotine administration enhances NPY expression in the rat hypothalamus. Brain Res 867: 157-164.

Liu RH, Kurose T, Matsukura S (2001). Oral nicotine administration decreases tumor necrosis factor-alpha expression in fat tissues in obese rats. Metabolism 50: 79-85.

McCarthy DO (2000). Tumor necrosis factor alpha and interleukin6 have differential effects on food intake and gastric emptying in fasted rats. Res Nurs Health 23: 222-228.1.

Morris MJ, Russell AE, Kapoor V, Cain MD, Elliott JM, West MJ et al (1986). Increase in plasma neuropeptide $\mathrm{Y}$ concentrations during sympathetic activation in man. J Auton Nerv Syst 17: 143-149.

Nagase I, Yoshida T, Kumamoto K, Umekawa T, Sakane N, Nikami $\mathrm{H}$ et al (1996). Expression of uncoupling protein in skeletal muscle and white fat of obese mice treated with thermogenic 33-adrenergic agonist. J Clin Invest 97: 2898-2904.

O’Hara P, Connett JE, Lee WW, Nides M, Murray R, Wise R (1998). Early and late weight gain following smoking cessation in the lung health study. Am J Epidemiol 148: 821-830. 
Ouyang Y, Virasch N, Hao P, Aubrey MT, Mukerjee N, Bierer BE et al (2000). Suppression of human IL-1beta, IL-2, IFN-gamma, and TNF-alpha production by cigarette smoke extracts. J Allergy Clin Immunol 106: 280-287.

Perkins KA (1992). Effects of tobacco smoking on caloric intake. Br J Addict 87: 193-205.

Samec S, Seydoux J, Dulloo AG (1998). Role of UCP homologues in skeletal muscles and brown adipose tissue: mediators of thermogenesis or regulators of lipids as fuel substrate? FASEB J 12: 715-724.

Sivitz WI, Fink BD, Donohoue PA (1999). Fasting and leptin modulate adipose and muscle uncoupling protein: divergent effects between messenger ribonucleic acid and protein expression. Endocrinology 140: 1511-1519.

Sonti G, Ilyin SE, Plata-Salaman CR (1996). Anorexia induced by cytokine interactions at pathophysiological concentrations. $\mathrm{Am} \mathrm{J}$ Physiol 270: R1394-R1402.

Spiegelman BM, Hotamisligil GS (1993). Through thick and thin: wasting, obesity, and TNF alpha. Cell 73: 625-627.

Stamford BA, Matter S, Fell RD, Papanek P (1986). Effects of smoking cessation on weight gain, metabolism rate, caloric consumption, and blood lipids. Am J Clin Nutr 43: 486-494.

Stephens TW, Basinski M, Bristow PK, Bue-Valleskey JM, Burgett SG, Craft L et al (1995). The role of neuropeptide Y in the antiobesity action of the obese gene product. Nature 377: 530-532.

Swart I, Jahng JW, Overton JM, Houpt TA (2002). Hypothalamic NPY, AGRP, and POMC mRNA responses to leptin and refeeding in mice. Am J Physiol Regul Integr Comp Physiol 283: R1020-R1026.

Toomey D, Redmond HP, Bouchier-Hayes D (1995). Mechanisms mediating cancer cachexia. Cancer 76: 2418-2426.

Torti FM, Torti SV, Larrick JW, Ringold GM (1989). Modulation of adipocyte differentiation by tumor necrosis factor and transforming growth factor beta. J Cell Biol 108: 1105-1113.

Tracey KJ, Cerami A (1992). Tumor necrosis factor and regulation metabolism in infection: roles of systemic versus tissue levels. Proc Soc Exp Biol Med 200: 233-239.

Vaisman N, Hahn T (1991). Tumor necrosis factor-alpha and anorexia-cause or effect? Metabolism 40: 720-723.

Ventre J, Doebber T, Wu M, MacNaul K, Stevens K, Pasparakis M et al (1997). Targeted disruption of the tumor necrosis factoralpha gene: metabolic consequences in obese and nonobese mice. Diabetes 46: 1526-1531.

Wager-srdar SA, Levine AS, Morley JE, Hoidal JR, Niewoehner DE (1984). Effects of cigarette smoke and nicotine on feeding and energy. Physiol Behav 32: 389-395.

Wee CC, Rigotti NA, Davis RB, Phillips RS (2001). Relationship between smoking and weight control efforts among adults in the United States. Arch Intern Med 161: 546-550.

Wilding JP, Gilbey SG, Bailey CJ, Batt RA, Williams G, Ghatei MA et al (1993). Increased neuropeptide- $Y$ messenger ribonucleic acid (mRNA) and decreased neurotensin mRNA in the hypothalamus of the obese $(o b / o b)$ mouse. Endocrinology 132: 1939-1944.

Williamson DF, Madans J, Anda RF, Kleinman JC, Giovino GA, Byers T (1991). Smoking cessation and severity of weight gain in a national cohort. $N$ Engl J Med 324: 739-745.

Woods SC, Seeley Jr R, Porte Jr D, Schwartz MW (1998). Signals that regulate food intake and energy homeostasis. Science 280: $1378-1382$.

Yoshida T, Sakane N, Umekawa T, Kogure A, Kondo M, Kumamoto K et al (1999). Nicotine induces uncoupling protein 1 in white adipose tissue of obese mice. Int J Obes Relat Metab Disord 23: 570-575.

Zarjevski N, Cusin I, Vettor R, Rohner-Jeanrenaud F, Jeanrenaud B (1993). Chronic intracerebroventricular neuropeptide-Y administration to normal rats mimics hormonal and metabolic changes of obesity. Endocrinology 133: 1753-1758. 